\title{
A REVIEW OF THE CAUSES OF POSTOPERATIVE HYPOXIA*
}

\author{
G. R. SELLERY, M.D., DIP.ANAES., F.R.C.P.(C) $†$
}

ARTERIAL OXYGEN TENSIONS are reduced in the postoperative patient breathing air. This was studied by Gordh in $1958^{1}$ and by Nunn and Payne in $1962^{2}$ and was found to occur, despite normal ventilatory volumes and arterial carbon dioxide tensions, in patients whose preoperative cardiorespiratory status was normal.

The purpose of this review is to outline the physiological components and discuss the aetiological factors that may be important in a decreased postoperative $\mathrm{PO}_{2}$. The extent of the decreased arterial oxygen tension varied in different studies with the time of sampling and other conditions as shown in Table I. ${ }^{2-7}$

TABLE I

Examples of Postoperative $\mathrm{Po}_{2}$ in Patients Breathing Air

\begin{tabular}{|c|c|c|}
\hline & Spontaneous & Controlled \\
\hline Marshall and Millar & 72 & - \\
\hline Conway and Payne & - & $68.3 \pm 8.4$ \\
\hline Nunn and Payne & 65 & $=$ \\
\hline Diament and Palmer & - & 73.8 \\
\hline Stephen and Talton & 80 (c stir-up) & - \\
\hline Toronto General & 69.1 & 69.2 \\
\hline
\end{tabular}

These levels are lower than expected and are of significance when related to the oxygen dissociation curve and myocardial oxygenation. ${ }^{8}$ In our study, for example, a $\mathrm{Po}_{2}$ of 50.9 was two standard deviations below the mean $\mathrm{Po}_{2}$ of 69.1 $\mathrm{mm}$. $\mathrm{Hg}$. At this $\mathrm{Po}_{2}$, the oxygen saturation is 83.5 per cent and the arterial oxygen content is only $11.2 \mathrm{ml}$. per cent when the haemoglobin is $10 \mathrm{gm}$. per cent, a common finding in the postoperative period (Fig. 1). As the myocardial arterio-venous oxygen difference is $12 \mathrm{ml}$. per cent, myocardial oxygenation in this example would only be achieved by increasing coronary blood flow. This may be impossible in the patient with narrowed coronary arteries. Therefore, the lowered $\mathrm{PO}_{2}$ values found in the postoperative patient are a definite cause for concern.

The physiological causes of a lowered arterial oxygen tension are shown in Table II. Hypoventilation will not be discussed, as the $\mathrm{Po}_{2}$ is low despite normal ventilation. There is no evidence to suggest true diffusion defects occur in the normal patient.

Ventilation/perfusion abnormalities (i.e., a relative decrease in ventilation) may occur and contribute to a lowered $\mathrm{PO}_{2}$ due to venous admixture. This effect can be prevented by oxygen enrichment (Fig. 2). ${ }^{9}$

'Presented in the Residents' Programme at the Annual Meeting of the Canadian Anaesthetists' Society, June 1967.

†Department of Anaesthesia, University of Toronto. 


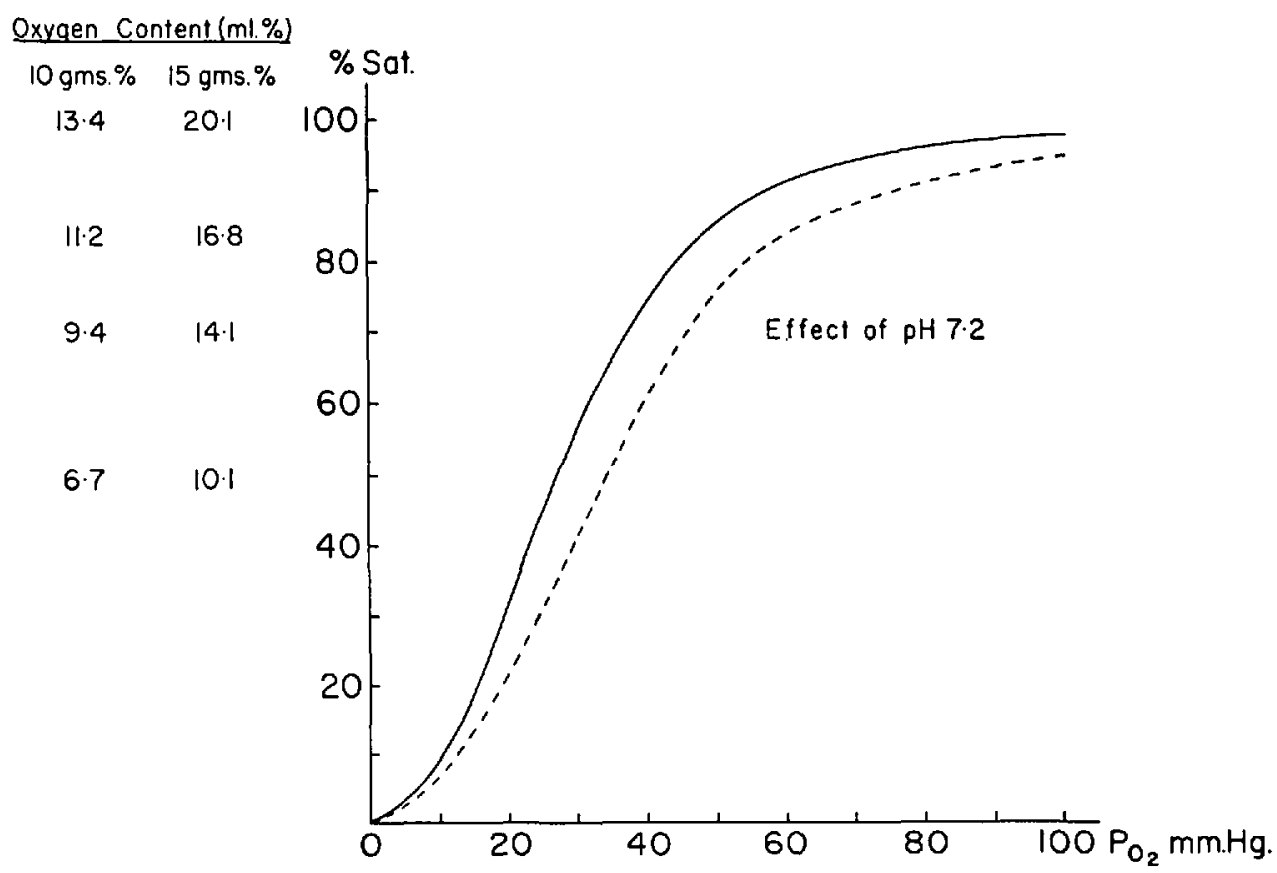

Figure 1. Oxygen dissociation curve.

TABLE II

Physiological Causes of Lowered Arterial Oxygen Content

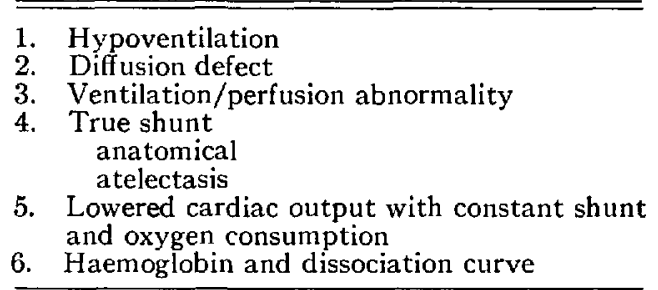

True shunting occurs when venous blood returns to the left heart without being oxygenated. During anaesthesia, shunting can develop due to small areas of atelectasis. Blood that perfuses unventilated alveoli is not oxygenated, so that end capillary oxygen content is low. This contributes to a lowered arterial oxygen content and therefore to a lowered $\mathrm{Po}_{2}$. The effect can not be overcome by oxygen enrichment. It is these small areas of atelectasis that are believed by some to be a major cause of postoperative hypoxia. ${ }^{10}$

Cardiac output, according to the Fick principle, is inversely proportional to the arterio-venous oxygen difference (Fig. 3).11 Mixed venous blood contains less oxygen when cardiac output is lowered. With a significant shunt, a decreased mixed venous oxygen content will result in a decreased arterial oxygen content. ${ }^{12}$ Therefore, with a given shunt, the $\mathrm{Po}_{2}$ is determined by the degree of 


\section{VENTILATION PERFUSION ABNORMALITY}

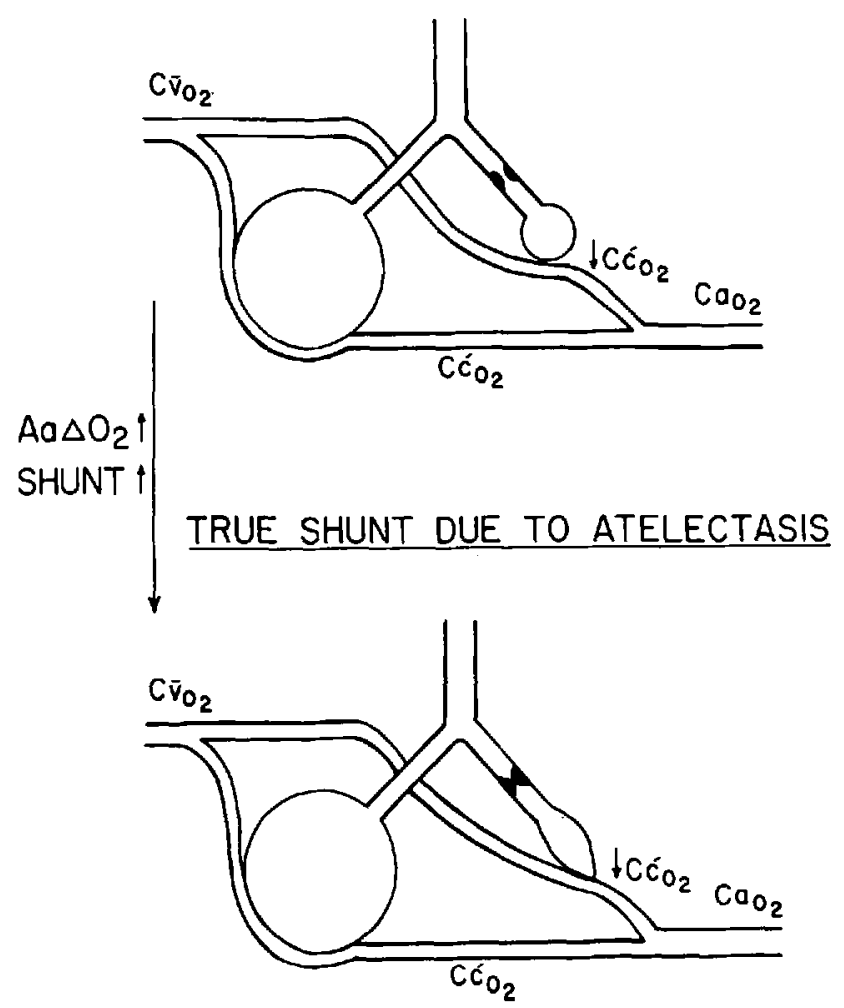

Figure 2

desaturation of the blood going through the shunt. A significant degree of hypotension due to low cardiac output will lower the arterial oxygen tension.

The haemoglobin level will affect the oxygen content. Also, a shift of the oxygen dissociation curve to the right will result in a decreased saturation at a given $\mathrm{Po}_{2}{ }^{13}$

\section{Aetiological Factors and Them Prevention}

The preoperative factors are listed in Table III. The preoperative values in patients with a normal cardiorespiratory status were found to be lower than expected. They varied in different studies, depending on the time of sampling and whether the patients had been ambulatory just prior to sampling.,.$^{3,5-7,14-17}$ Hamilton noted two apparently healthy patients with values of 62 and $56 \mathrm{~mm}$. $\mathrm{Hg}$. Conway felt that it was natural for the $\mathrm{Po}_{2}$ to be lower in the patient who had been supine for a long period.

Age has been found by many workers to affect the $\mathrm{Po}_{2}$. Nunn found that the $\mathrm{PO}_{2}$ was lower in patients over 43 , and he drew a regression line showing that the $\mathrm{Po}_{2}$ decreased as age increased. ${ }^{18}$ 


$$
\begin{aligned}
\text { C.O. } & =\frac{\mathrm{O}_{2} \text { CONSUMPTION }}{\mathrm{A}-\mathrm{V} \mathrm{O}_{2} \text { DIFFERENCE }} \\
\downarrow \text { c.O. } & \rightarrow \uparrow \mathrm{A}-\mathrm{V} \Delta \mathrm{O}_{2} \text { or } \downarrow \mathrm{C}_{\mathrm{O}_{2}}
\end{aligned}
$$

SHUNT EQUATION:

$$
\frac{Q_{S}}{Q_{T}}=\frac{C c_{02}-C_{O_{2}}}{C c_{02}-C \bar{V}_{02}}
$$

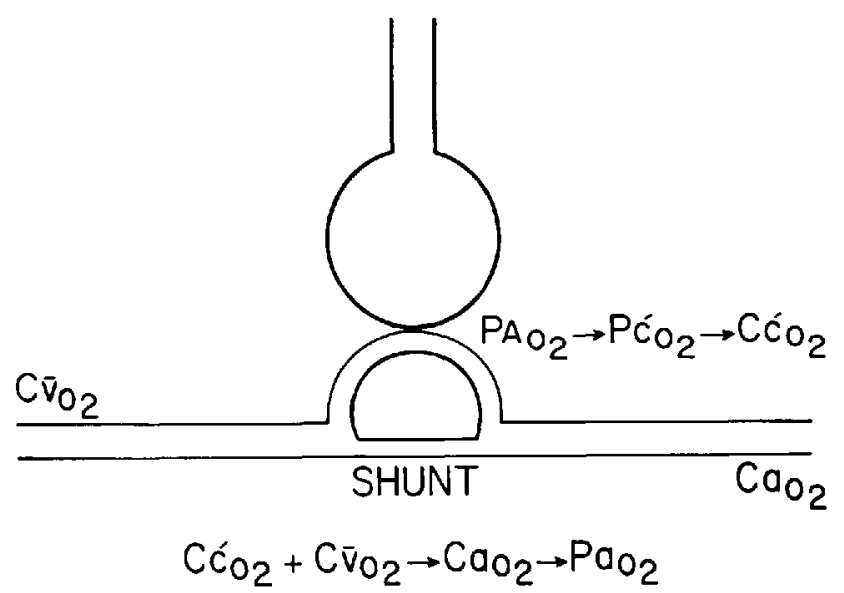

Figure 3. Effect of cardiac output on $\mathrm{Pa}_{\mathrm{O}_{2}}$.

TABLE III

Preoperative Aetiological Factors of Postoperative Hypoxia

\begin{tabular}{ll}
\hline \hline 1. Preoperative values & \\
Stevens and Hamilton & 84.3 \\
Diament and Palmer & 92.4 \\
Stephen and Talton & 80.4 \\
Marshall and Millar & 86.0 \\
Hamilton et al. & 76.5 \\
Conway et al. & 91.8 \\
Lewis and Welch & 81.4 \\
Toronto General Study & 82.2 \\
(range 66.2-99.4) &
\end{tabular}

2. Age

$$
\text { (range 66.2-99.4) }
$$

3. Premedication
(a) atropine

(b) narcotic

4. Cardiorespiratory pathology

Premedication with atropine and/or narcotic will lead to changes. Conway and his colleagues studied the effect of atropine premedication and found that the mean $\mathrm{Po}_{2}$ in the postoperative period of the atropine group was $15 \mathrm{~mm}$. $\mathrm{Hg}$. below that of the control group. ${ }^{19}$ However, Nunn could not find a correlation between atropine premedication and postoperative hypoxia. ${ }^{20}$ 
The effect of narcotic premedication was studied by Pierce and his colleagues, ${ }^{21}$ who found that a combination of meperidine, promethazine, and pentobarbital changed the $\mathrm{Po}_{2}$ from 83.8 to 67.0 one hour later, whereas, when the pentobarbital alone was given, there was little change. It was concluded that the narcotics depress the sigh reflex. This might lead to atelectasis and venous admixture. Marshall and Millar found that narcotic premedication decreased the mean $\mathrm{PO}_{2}$ by $14 \mathrm{~mm}$. Hg. ${ }^{3}$ Although a low preoperative $\mathrm{Po}_{2}$ does not necessarily result in a low one postoperatively, it is likely to have some effect.

During the anaesthetic period, factors arise that may contribute to postoperative hypoxia. These are listed in Table IV. The effect of anaesthetic technique contributes to this in many ways.

TABLE IV

Peroperative Aetiological Factors of Postoperative Hypoxia

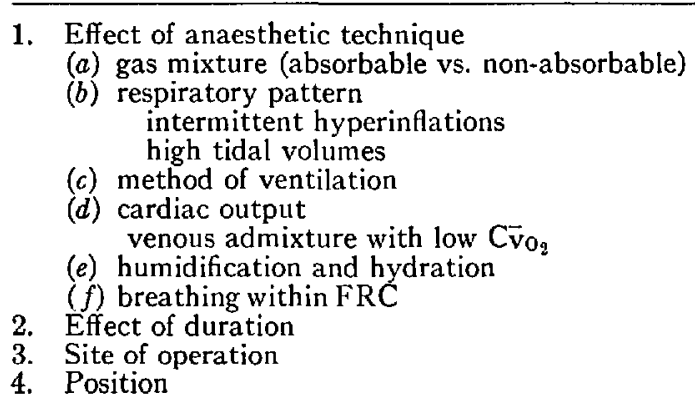

It has been postulated that the use of absorbable gases such as oxygen and nitrous oxide might lead to increased atelectasis. Déry et al. showed that the addition of nitrogen to the mixture would prevent a decrease in functional residual capacity (F.R.C.) and prevent atelectasis. ${ }^{22}$ However, Webb and others have used 50 per cent nitrogen in the gas mixture and have not been able to demonstrate any improvement over the use of nitrous oxide. ${ }^{23}$ Therefore, the effect of a gas mixture containing a non-absorbable gas to maintain the aveolar architecture is uncertain.

The pattern of respiration in the conscious patient includes a sigh about ten times per hour. This sigh reflex prevents alveolar collapse. During anaesthesia, the sigh reflex is deficient and thus miliary atelectasis may occur with a resultant decrease in $\mathrm{Po}_{2}$. Bendixen and his colleagues felt they could substitute for the normal sigh reflex intermittent hyperinflations with the anaesthetic mixture.10 After each hyperinflation, the $\mathrm{Po}_{2}$ rose to near normal preoperative values. However, Nunn found that a hyperinflation that was of value would require inflation to a pressure of $40 \mathrm{~cm} . \mathrm{H}_{2} \mathrm{O}$ and maintenance for 40 seconds. ${ }^{24}$ This resulted in severe cardiovascular depression due to the high mean intrathoracic pressure attained. We studied the effects of periodic hyperinflations carried out every ten minutes during anaesthesia with the anaesthetic mixture, using volumes equal to three times the predicted tidal volume. We found no statistical difference between the oxygen tensions of those patients in the recovery room breathing air 
who had had hyperinflations and the tensions of the control group. ${ }^{7}$ This indicates that the effects of hyperinflations do not last into the recovery period.

The method of ventilation is a factor because, during controlled ventilation, gas is forced to the uppermost parts of the lung while perfusion is greater in the lowermost. ${ }^{26}$ This tends to lead to decreased ventilation relative to perfusion in the lowermost parts, resulting in a lowered $\mathrm{Po}_{2}$. Marshall and Millar showed that patients having controlled ventilation had a greater decrease in $\mathrm{Po}_{2}$ than those breathing spontaneously. ${ }^{3}$ In patients having controlled ventilation, Sykes and his colleagues ${ }^{27}$ as well as Bendixen ${ }^{28}$ found that ventilation with high tidal volumes would protect against a drop in arterial oxygen tension provided there was no reduction in cardiac output. However, excessive hyperventilation with air has been shown by Fairley ${ }^{13}$ to increase the alveolar-arterial oxygen difference when the values are plotted on the $\mathrm{PO}_{2}-\mathrm{PcO}_{2}$ diagram of Fenn and $\mathrm{Rahn}^{25}$ (Fig. 4). In some patients therefore, a drop in $\mathrm{Pco}_{2}$ can result in a decreased $\mathrm{Po}_{2}$, depending on the physiological shunt and the cardiac output.

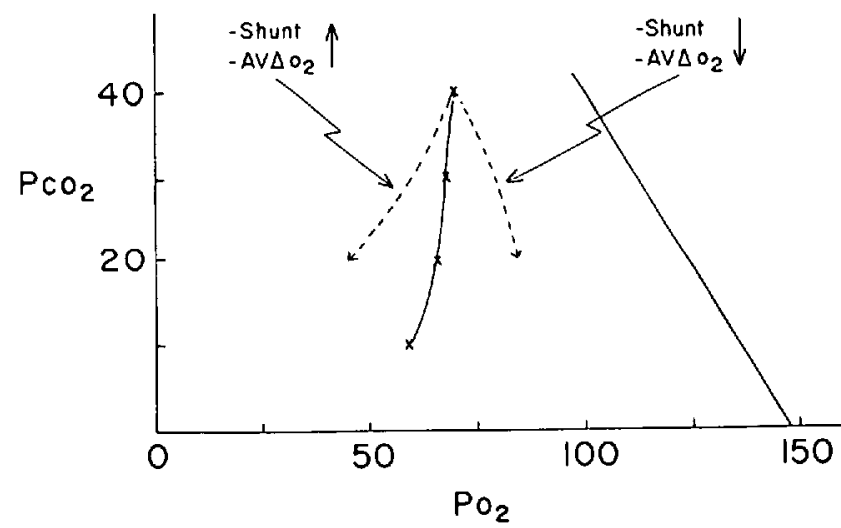

Figure 4 (published by permission of Dr. H. B. Fairley)

Any of the causes of a decreased cardiac output during anaesthesia will lead to an increased arterio-venous oxygen difference and therefore a lowered $\mathrm{PO}_{2}$ (Fig. 4). Fairley ${ }^{29}$ has presented theoretical considerations illustrating that an increased arterio-venous difference and an increased shunt will lead to a decreased $\mathrm{PO}_{2}$. Kelman and his group ${ }^{30}$ have suggested that the enlarged alveolar-to-arterial oxygen tension difference was due to a decrease in cardiac output in the presence of a normal venous admixture. This is contrary to the concept of atelectasis and ventilation/perfusion abnormalities as the main factors in producing postoperative hypoxia. Prys-Roberts ${ }^{31}$ showed that a decrease in $\mathrm{PO}_{2}$ paralleled the reduction in cardiac output when thiopentone was given. $\mathrm{He}$ also showed that the $\mathrm{PO}_{2}$ dropped when the cardiac output was reduced by hyperventilation. Therefore, any factor that will cause a reduced cardiac output extending into the postoperative period will result in a degree of postoperative hypoxia. 
Inadequate humidification and hydration have been postulated as factors contributing to miliary atelectasis. The resulting dry gases can lead to ciliary paralysis and dry retained secretions. ${ }^{32}$ Our investigation ${ }^{7}$ of the effect of adequate hydration and humidification showed that hydration and the insertion of an "artificial nose" 33 in the circuit did not prevent a decreased $\mathrm{Po}_{2}$. We also studied the effect on postoperative $\mathrm{Po}_{2}$ of inserting a Puritan nebulizer in the circuit and found no difference in the values between the treatment and control groups. ${ }^{7}$ Indeed Déry suggests that artificial airways maintain normal heat and moisture exchange even though they bypass the nose. ${ }^{34}$

$\mathrm{Nunn}^{35}$ has found that breathing with forced expirations at normal tidal volumes (i.e., within the F.R.C.) will lead to collapse. This may occur when the patient is straining on the endotracheal tube or in patients with bronchospasm. Bronchospasm can occur occasionally at the termination of anaesthesia and contribute to postoperative hypoxia.

The duration of the procedure has been suggested as a factor contributing to $\mathrm{Po}_{2}$ decrease. Marshall and Millar ${ }^{3}$ noted no decrease in the postoperative $\mathrm{Po}_{2}$ after minor surgery with a mean duration of 10 minutes. However, there was a definite decrease following major surgery with a mean duration of 68 minutes. Our study ${ }^{7}$ revealed no correlation between duration and postoperative $\mathrm{Po}_{2}$, although no procedures were under 30 minutes in length.

The site of operation will affect the degree of postoperative hypoxia. Surgery on the chest and heart would be expected to result in a lowered $\mathrm{Po}_{2}$ due to pathology, but the drop is significant even after procedures done on the periphery. Abdominal surgery leaves the patient with reduced capacity for the sigh reflex, deep breathing, and coughing. Diament and $\mathrm{Palmer}^{5}$ showed that the $\mathrm{PO}_{2}$ following upper abdominal surgery was about $10 \mathrm{~mm}$. $\mathrm{Hg}$. below that following lower abdominal surgery.

The position of the patient is important as it affects cardiac output. As was stated earlier, any factor that decreases cardiac output when there is a significant shunt will also decrease arterial oxygen tension. This can occur in the lateral kidney position with kinking of the inferior vena cava or in the unbolstered prone position with resulting decreased venous return.

A number of factors in the immediate postoperative period will affect the $\mathrm{Po}_{2}$, as shown in Table V. Diffusion hypoxia, as described by Fink, ${ }^{36}$ occurs when nitrous oxide comes quickly out of solution in the blood at the end of the anaesthetic. This dilutes the alveolar gas and results in a short period of hypoxia in the patient breathing air. Millar ${ }^{3}$ stated that a patient's $\mathrm{Po}_{2}$ would drop by $10 \mathrm{~mm}$. Hg. at fifteen minutes if the patient had had 70 per cent nitrous oxide. This drop was negligible after 30 minutes.

Air inflations at the termination of anaesthesia were suggested by Déry ${ }^{22}$ to re-expand collapsed alveoli and maintain the $\mathrm{Po}_{2}$ at near preoperative values. The results of our study ${ }^{37}$ of this problem revealed no statistical difference between the group having air inflations and the controls. Stevens and Hamilton ${ }^{14}$ produced results similar to our own. It is unlikely that this procedure will prevent the low postoperative $\mathrm{Po}_{2}$.

Any factor that inhibits the sigh reflex, such as sedation, tight binders, or 
TABLE $V$

Postoperative Factors of

Postoperative Hypoxia

1. Diffusion hypoxia

2. Air inflations

3. Inhibition of the sigh reflex

DISCUSSION

$\downarrow \mathrm{PO}_{2}\left\{\begin{array}{l}\uparrow \text { venous admixture } \\ \downarrow \text { cardiac output }\end{array}\left\{\begin{array}{l}\text { true shunt } \\ \mathrm{Va} / \mathrm{Q} \downarrow\end{array}\right.\right.$
PREVENTION
$\mathrm{O}_{2}$ enrichment
Vigorous stir-up routine
Maintenance of cardiac output

incisional pain, may decrease normal surface activity within the alveoli and lead to miliary atelectasis. Hamilton ${ }^{15}$ states that the "stir-up" regimen will prevent low constant tidal volumes and thus improve the postoperative $\mathrm{Po}_{2}$. However, Stephen and Talton ${ }^{6}$ found that patients breathing air and receiving a vigorous stir-up routine still had subnormal values.

\section{Discussion}

The decreased arterial oxygen tension in the postoperative period is likely due to a combination of increased venous admixture from true shunt and/or ventilation-perfusion abnormality, and to decreased cardiac output. Many of the factors noted will affect both physiological components.

The prevention of a low postoperative $\mathrm{Po}_{2}$ begins prior to anaesthesia and extends through the postoperative period. The most important time is immediately after the termination of surgery in the operating room when the effects of diffusion hypoxia, hypotension, respiratory depression, and atelectasis are the greatest. It is at this time that myocardial oxygenation is likely to be at its lowest and it is at this time that the patient often receives the least amount of care and supervision. Oxygen enrichment should be continuous from the termination of surgery to the recovery room in order to remove the contribution of ventilation perfusion abnormality. A vigorous stir-up routine should be carried out to reduce the effect of shunting from atelectasis. The effect of cardiac output on the postoperative $\mathrm{PO}_{2}$ is one more reason to prevent this from occurring.

\section{SUMMARY}

Postoperative hypoxia occurs to a significant degree in healthy patients breathing air following surgery. The preoperative values are lower than was previously thought. The possible aetiological factors and their prevention have been discussed, and suggestions have been made to minimize the decrease in postoperative arterial oxygen tension. 


\section{RÉSUMÉ}

La diminution de la tension d'oxygène dans le sang artériel au cours de la période postopératoire est attribuable, selon toute vraisemblance, à un groupe de facteurs: soit à la suite d'une augmentation du mélange veineux à cause d'une vraie dérivation (shunt), soit à cause d'un état anormal de ventilation/perfusion, soit à cause d'une diminution du débit cardiaque. Plus d'un de ces facteurs mentionnés peut modifier les deux composantes physiologiques.

La prévention de l'abaissement de la $\mathrm{Po}_{2}$ au cours des suites opératoires commence avant l'anesthésie et se continue au cours de la période post-opératoire. Le moment le plus important se situe immédiatement à la fin de la chirurgie dans la salle d'opération alors que les effets de l'hypoxie de diffusion, l'hypotension, la dépression respiratoire et l'atélectasie sont les plus marqués. C'est à ce moment-là que l'oxygénation du myocarde est probablement à son plus bas et c'est au même moment que, souvent, le malade reçoit moins de soins et de surveillance. Une généreuse oxygénation devrait être continuelle entre la fin de la chirurgie et l'arrivée du malade à la salle de réveil de façon à éliminer le facteur de déséquilibre de la ventilation/perfusion. Il faut appliquer une routine vigoureuse d'inclinaison pour diminuer l'effet de la dérivation dû à l'atélectasie. L'effet du débit cardiaque sur la $\mathrm{Po}_{2}$ post-opératoire est une autre raison pour justifier cette routine.

En somme, l'hypoxie post-opératoire survient à un degré assez marqué chez les malades en bonne santé qui sont laissés à l'air libre après la chirurgie. Les données préopératoires sont inférieures à celles présumées. Nous avons discuté des facteurs étiologiques possibles et de leur prévention et nous avons fait des suggestions pour réduire au minimum la tension de $\mathrm{O}_{2}$ dans le sang artériel au cours des suites opératoires.

\section{REFERENCES}

1. Gordh, T. Pulmonary Function in Relation to Anaesthesia and Surgery Evaluated by Analysis of Oxygen Tension of Arterial Blood. Acta anaesth. scandinav. 2: 15 (1958).

2. Nunn, J. F. \& PAXne, J. P. Hypoxaemia after General Anaesthesia. Lancet. ii: 631 (1962)

3. Marshald, B. E. \& Millah, R. A. Some Factors Influencing Postoperative Hypoxia. Anaesthesia. 20: 408 (1965).

4. Conway, C. M. \& Payne, J. P. Hypoxaemia Associated with Anaesthesia and Controlled Respiration. Lancet. $i$ : 12 (1964).

5. Diament, M. L. \& Palmer, K. N. V. Postoperative Changes in Gas Tensions of Arterial Blood and in Ventilatory Function. Lancet. $i i$ : 180 (1966).

6. Stephen, C. R. \& Talton, I. Immediate Postoperative Care, with Particular Reference to Blood Gas Studies. Canad. Anaesth. Soc. J. 11: 586 (1964).

7. Fatrley, H. B.; Kerr, J. H.; Laws, A. K.; \& Selleny, G. R. The Avoidance of Postoperative Hypoxaemia: An Assessment of Three Techniques for Use During Anaesthesia. Canad. Anaesth. Soc. J. 15: 152 (1968).

8. Bendixen, H. H. \& Laver, M. B. Hypoxia in Anesthesia: A Review. Clin. Pharmacol. \& Therap. 6: 510 (1965).

9. Comroe, J. H. Jr.; Fonster, R. E. II; Dubois, A. B.; Briscoe, W. E.; \& Carlsen, E. The Lung, Chicago: Year Book Publishers Inc. (1962).

10. Bendixen, H. H.; Bullwinkel, B.; Hedley-Whyte, J.; \& Laver, M. B. Atelectasis and Shunting during Spontaneous Ventilation in Anesthetised Patients. Anesthesiology 25: 297 (1964). 
11. Rushmer, R. T. Cardiovascular Dynamics. W. B. Saunders Co. (1961).

12. Greenbaum, R.; Kelman, G. R.; Nunn, J. F.; \& Prys-Roberts, C. Arterial Oxygen Tensions. Correspondence. Anesthesiology. 27: 869 (1966).

13. FarRley, H. B. The Oxygen Tightrope. Canad. Anaesth. Soc. J. 13: 98 (1966).

14. Stevens, W. C.; Gossetr, J. A.; Hamilton, W. K.; \& Morehead, R. T. The Relation of Postoperative Atelectasis to the Solubility of Gas Filling the Lungs at Termination of Anesthesia. Anesthesiology. 27: 163 (1966).

15. Hamilton, W. K.; McDonald, J. S.; Fisher, H. W.; \& Bethards, R. Postoperative Respiratory Complications: A Comparison of Arterial Gas Tensions, Radiographs and Physical Examination. Anesthesiology. 25: 607 (1964).

16. Conway, C. M.; Payne, J. P.; \& Tombin, P. J. Arterial Oxygen Tensions of Patients Awaiting Surgery. Brit. J. Anaesth. 37: 405 (1965).

17. Lewis, F. J. \& Welch, J. A. Respiratory Mechanics in Postoperative Patients. Surg. Gynaec. \& Obstet. 120: 305 (1965).

18. Nunn, J. F. Influence of Age and Other Factors on Hypoxaemia in the Postoperative Period. Lancet. ii: 466 (1965).

19. Conway, C. M. Arterial Oxygen Tensions in Surgical Patients: A Symposium on Oxygen Measurements in Blood and Tissues and Their Significance. Edited by J. P. Payne and D. W. Hill. J. and A. Churchill Ltd. (1966).

20. Nunn, J. F. \& Bergman, N. A. The Effect of Atropine on Pulmonary Gas Exchange. Brit. J. Anaesth. 36: 68 (1964).

21. Pierce, J. A. \& Garofalo, M. L. Preoperative Medication and Its Effect on Blood Gases. J.A.M.A. 194: 487 (1965).

23. Déry, R.; Pelletier, J.; Jacques, A.; Clavet, M.; \& Houde, J. Alveolar Collapse Induced by Denitrogenation. Canad. Anaesth. Soc. J. 12: 531 (1965).

23. WeBB, S. J. S. \& NUNN, J. F. A Comparison between the Effect of Nitrous Oxide and Nitrogen on Arterial $\mathrm{Po}_{2}$. Anaesthesia. 22: 69 (1967).

24. NunN, J. F.; Bergman, N. A.; \& Coleman, A. J. Factors Influencing the Arterial Oxygen Tension during Anaesthesia with Artificial Ventilation. Brit. J. Anaesth. 37: 898 (1965).

25. RaHN, H. \& FENN, W. O. The $\mathrm{O}_{2}-\mathrm{CO}_{2}$ Diagram: A Graphical Analysis of the Respiratory Gas Exchange. Washington, D.C.: Am. Physiol. Soc. (1955).

26. West, J. B. Blood Flow, Ventilation and Gas Exchange in the Lung. Lancet. ii: 1055 (1963).

27. Sykes, M. K.; Young, W. E.; \& Robinson, B. E. Oxygenation during Anaesthesia with Controlled Ventilation. Brit. J. Anaesth. 37: 314 (1965).

28. Bendixen, H. H.; Hedley-Whyte, J.; \& Lavar, M. B. Impaired Oxygenation in Surgical Patients during General Anesthesia with Controlled Ventilation. New England J. Med. 269: 823 (1963).

29. FafrLeY, H. B. The Effect of Hyperventilation on Arterial Oxygen Tension: A Theoretical Analysis. Canad. Anaesth. Soc. J. 14: 87 (1967).

30. Kelman, G. R.; Nunn, J. F.; Prys-Roberrs, C.; \& Greenbaum, R. The Influence of Cardiac Output on Arterial Oxygenation: A Theoretical Study. Brit. J. Anaesth. 39: 450 (1967).

31. Phys-Roberts, C. \& Greenbaum, R. The Influence of Circulatory Factors on Arterial Oxygenation during Anaesthesia in Man. Anaesthesia. 22: 257 (1967).

32. Wyire, W. D. \& Churchiml-Davmson, H. C. A Practice of Anaesthesia. Chicago: Year Book Medical Publishers (1966).

33. Toremalm, N. G. Postoperative Care and Complications after Tracheotomy in Infants and Children. Acta anaesth. scandinav. 4: 105 (1960).

34. Déry, R.; Pelletier, J.; Jacques, A.; Clavet, M.; \& Houde, J. J. Humidity in Anaesthesiology: III. Heat and Moisture Patterns in the Respiratory Tract during Anaesthesia with the Semi-Closed System. Canad. Anaesth. Soc. J. 14: 287 (1967).

35. Nunn, J. F.; Coleman, A. J.; Sachithanandan, R.; Bergman, N. A.; \& Laws, J. W. Hypoxaemia and Atelectasis Produced by Forced Expiration. Brit. J. Anaesth. 37: 3 (1965).

36. FINK, B. R. Diffusion Anoxia. Anesthesiology. 16: 511 (1955).

37. Fairley, H. B.; Kerr, J. H.; LAw, A. K.; \& Sellery, G. R. Unpublished data. 